\title{
Reaction kinetics, reaction products and compressive strength of ternary activators activated slag designed by Taguchi method
}

\section{Citation for published version (APA):}

Yuan, B., Yu, Q. L., \& Brouwers, H. J. H. (2015). Reaction kinetics, reaction products and compressive strength of ternary activators activated slag designed by Taguchi method. Materials \& Design, 86, 878-886.

https://doi.org/10.1016/j.matdes.2015.07.077

\section{Document license:}

TAVERNE

DOI:

10.1016/j.matdes.2015.07.077

Document status and date:

Published: 01/01/2015

\section{Document Version:}

Publisher's PDF, also known as Version of Record (includes final page, issue and volume numbers)

\section{Please check the document version of this publication:}

- A submitted manuscript is the version of the article upon submission and before peer-review. There can be important differences between the submitted version and the official published version of record. People interested in the research are advised to contact the author for the final version of the publication, or visit the DOI to the publisher's website.

- The final author version and the galley proof are versions of the publication after peer review.

- The final published version features the final layout of the paper including the volume, issue and page numbers.

Link to publication

\footnotetext{
General rights

- You may freely distribute the URL identifying the publication in the public portal. follow below link for the End User Agreement:

www.tue.nl/taverne

\section{Take down policy}

If you believe that this document breaches copyright please contact us at:

openaccess@tue.nl

providing details and we will investigate your claim.
}

Copyright and moral rights for the publications made accessible in the public portal are retained by the authors and/or other copyright owners and it is a condition of accessing publications that users recognise and abide by the legal requirements associated with these rights.

- Users may download and print one copy of any publication from the public portal for the purpose of private study or research.

- You may not further distribute the material or use it for any profit-making activity or commercial gain

If the publication is distributed under the terms of Article $25 \mathrm{fa}$ of the Dutch Copyright Act, indicated by the "Taverne" license above, please 


\title{
Reaction kinetics, reaction products and compressive strength of ternary activators activated slag designed by Taguchi method
}

\author{
B. Yuan *, Q.L. Yu, H.J.H. Brouwers \\ Department of the Built Environment, Eindhoven University of Technology, P.O. Box 513, 5600 MB Eindhoven, The Netherlands
}

\section{A R T I C L E I N F O}

\section{Article history:}

Received 16 March 2015

Received in revised form 26 May 2015

Accepted 13 July 2015

Available online 30 July 2015

\section{Keywords:}

Ternary activators

Slag

Taguchi experiment design

Reaction kinetics

FTIR

Compressive strength

\begin{abstract}
A B S T R A C T
This study investigates the reaction kinetics, the reaction products and the compressive strength of slag activated by ternary activators, namely waterglass, sodium hydroxide and sodium carbonate. Nine mixtures are designed by the Taguchi method considering the factors of sodium carbonate content (SCC), water to solid ratio (WSR), waterglass modulus (WGM) and waterglass content (WGC), and the experimental results are evaluated by applying the analysis of variance (ANOVA) method. The results show that ternary activators determine the reaction kinetics, sodium carbonate dominates the gel structure of reaction products, while the waterglass dosage is a determinant of the compressive strength. Based on the analyzed results, an optimal proportion of ternary alkali activators (SCC 4\%, WGC $2.5 \%$, WGM $1.1-1.5$ and WSR 0.4 ) is proposed.
\end{abstract}

(c) 2015 Elsevier Ltd. All rights reserved.

\section{Introduction}

During the last decade, considerable researches have been conducted on alkali activated materials (AAM) because of their superior properties and environmental benefits. It is known that alkali nature is a determinant of the mechanical properties and microstructure of alkali activated slag (AAS) [1-3]. Though waterglass is often reported as the most effective activator in AAS regarding strength and durability [4,5], the production of waterglass involves high energy consumption when melting quartz and soda at about $1300{ }^{\circ} \mathrm{C}$ [6], and thus has a significant $\mathrm{CO}_{2}$ footprint. Moreover, problems of fast setting and high shrinkage are also widely reported [2,7-12]. Chang [11] observed that the initial setting time of waterglass activated slag significantly drops to about 20 min when the dosage of alkali activator $\left(\mathrm{Na}_{2} \mathrm{O}+\mathrm{SiO}_{2} \mathrm{~g} / \mathrm{L}\right)$ is higher than $200 \mathrm{~g} / \mathrm{L}$ with the waterglass modulus of 1.01. On the other hand, few admixtures, such as retarder and superplasticizer, were reported to be effective due to the high $\mathrm{pH}$ environment of AAM [3,13-15]. Therefore, low usage of waterglass is preferred in respect of environment issue and fresh paste behavior. However, diluted alkaline solution often leads to weakened mechanical properties and durability. Concerning the resulted material properties, a combination of waterglass with other alkaline solutions as activator would lead to desired reaction products.

Comparing to waterglass activated slag, the mechanical properties of slag activated by sodium hydroxide or sodium carbonate are relatively

\footnotetext{
* Corresponding author.

E-mail address: B.Yuan@tue.nl (B. Yuan).
}

poor $[1,12,16]$ and thus they are of less interest to the practical application. Moreover, delayed reaction rate of $\mathrm{Na}_{2} \mathrm{CO}_{3}$ activated slag is observed [17,18], due to the initial precipitation of $\mathrm{CaCO}_{3}$ [2]. Previously, additional sodium hydroxide was employed to accelerate the reaction of sodium carbonate activated slag [18-20]. However, it is wise to note that the compressive strength of slag activated by these hybrid activators at $28 \mathrm{~d}$ generally ranges between $15 \mathrm{MPa}$ and $45 \mathrm{MPa}$, similar as slag activated by sole sodium carbonate [21]. To summarize, the incorporation of sodium hydroxide provides positive effect on the reaction rate of sodium carbonate activated slag, but its contribution on the strength development at later age is negligible.

Considering the fact that waterglass activated slag has the potential problem of fast setting while slag activated by $\mathrm{Na}_{2} \mathrm{CO}_{3}$ suffers lengthened dormant period, a mixture of waterglass and sodium carbonate as activator can potentially lead to desired reaction rate and mechanical properties of AAS. However, few researches have been conducted on this ternary alkali activator system. One possible reason could be the complexity of the influential factors, including waterglass content, waterglass modulus, $\mathrm{Na}_{2} \mathrm{CO}_{3}$ content and water to solid ratios. A full factorial experiment concerning these four factors each at three levels needs 81 mix designs. Apparently investing all of these parameters is time-consuming and costly. However, with an appropriate design of experiment, factors affecting the material properties can be properly evaluated, while the number of experiments can be significantly reduced. Taguchi experiment design is one of the widely applied methods for designing parameters for a specific problem, by using the minimal number of test series to represent a full factorial experiment [22]. By far Taguchi method has been applied in AAM [23-27]. Mijarsh 
et al. [26] studied the effect of six factors each at five levels by a total of 25 mixtures applying the Taguchi method L25 on the compressive strength of treated palm oil fuel ash based geopolymer. A sample with a $7 \mathrm{~d}$ compressive strength of $47.27 \pm 5.0 \mathrm{MPa}$ was obtained. Olivia and Nikraz [27] evaluated the influence of aggregate content, alkaline solution to fly ash ratio, sodium silicate to sodium hydroxide ratio and curing method on the mechanical properties of fly ash based geopolymer concrete by 9 mixtures, applying Taguchi method L9. The compressive strength of the optimal mixture can be up to $54.89 \mathrm{MPa}$ at 28 days, and the optimal mixture has higher tensile and flexural strength, produces less expansion and drying shrinkage, and shows a modulus of elasticity $14.9-28.8 \%$ lower than that of OPC control mix [27].

This work aims to investigate the optimal design of ternary alkali activators in order to achieve a well-performing mixture with respect to reaction rate and mechanical properties. Four influential factors on the reaction kinetics and compressive strength are evaluated. The content of waterglass is within the range of $0.5-2.5 \%$ (equivalent $\mathrm{Na}_{2} \mathrm{O}$ by mass of slag), while sodium carbonate dosages (equivalent $\mathrm{Na}_{2} \mathrm{O}$ by mass of slag) of $3-5 \%$ are applied. The selected waterglass moduli of 1.1-1.5 are within the optimal range and water to solid ratio ranges from 0.4 to 0.5 . Nine mixtures (T1-9) were designed following the Taguchi method. In addition, nine mixtures of sole sodium carbonate activated slag (R1-9) were designed as reference samples. The reaction kinetics of the developed mixtures were investigated by applying an isothermal calorimeter. The resulted materials were characterized by X-ray diffraction (XRD) and Fourier transform infrared spectroscopy (FTIR). The compressive strength of the developed mixtures was tested at different ages. The experimental results were evaluated by applying the analysis of variance (ANOVA) method. By calculating the response index for each factor based on the single to noise ratio $(\mathrm{S} / \mathrm{N})$ principle [22], i.e. a higher $\mathrm{S} / \mathrm{N}$ provides a 'better' response, the effect of individual factor on the compressive strength and reaction heat release results of the mixtures are evaluated. Furthermore, to validate the obtained results, three additional mixtures (T10-12) were designed, tested and analyzed.

\section{Materials and methods}

\subsection{Materials}

The applied raw material is a ground granulated blast furnace slag (GGBFS). The oxide composition of the GGBFS was determined by using X-ray Fluorescence (XRF), and the results are shown in Table 1. The basic coefficient of slag, defined as $(\mathrm{CaO}+\mathrm{MgO}) /\left(\mathrm{SiO}_{2}+\mathrm{Al}_{2} \mathrm{O}_{3}\right)$, is calculated, yielding 0.99 . The specific density, determined by a gas pycnometer (AccuPyc II 1340 Pycnometer), is $2903 \mathrm{~kg} / \mathrm{m}^{3}$. The particle size distribution (PSD) of the GGBFS was measured by laser diffraction technique (Mastersizer 2000), with the $\mathrm{d}(0.5)$ of $19.18 \mu \mathrm{m}$.

The alkali activators used here consist of sodium carbonate (powder form, analytical grade), sodium hydroxide (pearl form, analytical grade) and waterglass (liquid solution). The waterglass used is a commercial sodium silicate solution $\left(\mathrm{Na}_{2} \mathrm{O} \cdot \mathrm{rSiO}_{2} \cdot \mathrm{nH}_{2} \mathrm{O}\right)$ composing of $28 \% \mathrm{SiO}_{2}$, $8 \% \mathrm{Na}_{2} \mathrm{O}$ and $64 \% \mathrm{H}_{2} \mathrm{O}$ by mass. Sodium hydroxide is used to modify the modulus of waterglass to reach the desired values. The alkali activators were firstly mixed with water to reach designed parameters and then cooled down to room temperature $\left(20 \pm 1{ }^{\circ} \mathrm{C}\right)$ prior to further use.

Table 1

Chemical composition of GGBFS determined by XRF.

\begin{tabular}{|c|c|c|c|c|c|c|c|c|c|c|c|}
\hline Components & $\mathrm{CaO}$ & $\mathrm{SiO}_{2}$ & $\mathrm{Al}_{2} \mathrm{O}_{3}$ & $\mathrm{Fe}_{2} \mathrm{O}_{3}$ & $\mathrm{~K}_{2} \mathrm{O}$ & $\mathrm{Na}_{2} \mathrm{O}$ & S-total & $\mathrm{MgO}$ & $\mathrm{TiO}_{2}$ & $\mathrm{Cl}$ & L.O.I. \\
\hline Weight (\%) & 36.97 & 34.02 & 13.03 & 0.46 & 0.46 & 0.34 & 1.22 & 9.78 & 0.97 & 0.01 & 2.70 \\
\hline
\end{tabular}


Table 2

Investigated factors and levels (The dosages of the alkali contents reflect the $\mathrm{Na}_{2} \mathrm{O}$ mass).

\begin{tabular}{llll}
\hline Parameter & Level 1 & Level 2 & Level 3 \\
\hline Sodium carbonate content (SCC) & $3.0 \%$ & $4.0 \%$ & $5.0 \%$ \\
Water to solid ratio (WSR) & 0.40 & 0.45 & 0.50 \\
Waterglass modulus (WGM) & 1.5 & 1.3 & 1.1 \\
Waterglass content (WGC) & $0.5 \%$ & $1.5 \%$ & $2.5 \%$ \\
\hline
\end{tabular}

reaction process, i.e. the formation of $\mathrm{C}-(\mathrm{A})-\mathrm{S}-\mathrm{H}$ gel. In overall, $\mathrm{T} 4$ shows the fastest reaction rate followed by $\mathrm{T} 8$ and $\mathrm{T} 7$, while $\mathrm{T} 9$ shows the slowest reaction rate.

The heat evolution of slag activated by sodium carbonate is presented in Fig. 2. It is obvious that slag activated by $\mathrm{Na}_{2} \mathrm{CO}_{3}$ is different from slag activated by $\mathrm{Na}_{2} \mathrm{O} \cdot \mathrm{rSiO}_{2}$ or ordinary cement [31-34], indicated by a very long dormant period (DP) of up to $70 \mathrm{~h}$. In addition, after the dissolution phase, a second peak appears at about 1-2 $\mathrm{h}$ before the main reaction peak (i.e. the third peak shown in Fig. 2a). Regarding the presence of $\mathrm{CO}_{3}^{2-}$ in the alkali activators, the second peak could be attributed to the initially precipitated calcium carbonate [2]. The relative setting time (RST) of samples ranges from $55 \mathrm{~h}$ to $100 \mathrm{~h}$ (Fig. 2b), which corresponds with the phenomenon that most samples remain unhardened 2 days after casting [35]. Moreover, with the same sodium carbonate content the total heat release at $7 \mathrm{~d}$ of the samples is similar, regardless of water amount.

Table 5 presents the comparison between slag activated by the ternary activators and by only sodium carbonate, including the time to reach the reaction peak (TRRP), peak height and 7 day total heat release. The results show that the TRRP, peak height and heat release of slag activated by the ternary activators at $7 \mathrm{~d}$ are higher than slag activated by sodium carbonate, and these values are highly related to the waterglass dosage. However, the acceleration effect of waterglass decreases with the decrease of the sodium carbonate content in the mixture. In the case of sodium carbonate content of $5 \mathrm{Na}_{2} \mathrm{O}$ wt.\%, the TRRP of mix T8 with the waterglass dosage of $2.5 \%$ shows a remarkable acceleration compared to its reference (R8), while mix T9 (waterglass,

Table 3

(a) Suggested levels from Taguchi method for four factors at three levels (L9 array); (b) mix design of the samples.

\begin{tabular}{|c|c|c|c|c|}
\hline \multicolumn{5}{|c|}{ Table 3a } \\
\hline Mix & $\begin{array}{l}\text { Level of } \\
\text { Factor SCC }\end{array}$ & $\begin{array}{l}\text { Level of } \\
\text { Factor WSR }\end{array}$ & $\begin{array}{l}\text { Level of } \\
\text { Factor WGM }\end{array}$ & $\begin{array}{l}\text { Level of } \\
\text { Factor WGC }\end{array}$ \\
\hline 1 & 1 & 1 & 1 & 1 \\
\hline 2 & 1 & 2 & 2 & 2 \\
\hline 3 & 1 & 3 & 3 & 3 \\
\hline 4 & 2 & 1 & 2 & 3 \\
\hline 5 & 2 & 2 & 3 & 1 \\
\hline 6 & 2 & 3 & 1 & 2 \\
\hline 7 & 3 & 1 & 3 & 2 \\
\hline 8 & 3 & 2 & 1 & 3 \\
\hline 9 & 3 & 3 & 2 & 1 \\
\hline \multicolumn{5}{|c|}{ Table $3 b$} \\
\hline \multirow[t]{2}{*}{ Mix } & SCC & WSR & WGM & WGC \\
\hline & $\mathrm{Na}_{2} \mathrm{O}$ wt.\% & & & $\mathrm{Na}_{2} \mathrm{O}$ wt.\% \\
\hline $\mathrm{T} 1$ & 3 & 0.40 & 1.5 & 0.5 \\
\hline $\mathrm{T} 2$ & 3 & 0.45 & 1.3 & 1.5 \\
\hline T3 & 3 & 0.50 & 1.1 & 2.5 \\
\hline $\mathrm{T} 4$ & 4 & 0.40 & 1.3 & 2.5 \\
\hline T5 & 4 & 0.45 & 1.1 & 0.5 \\
\hline T6 & 4 & 0.50 & 1.5 & 1.5 \\
\hline $\mathrm{T} 7$ & 5 & 0.40 & 1.1 & 1.5 \\
\hline T8 & 5 & 0.45 & 1.5 & 2.5 \\
\hline T9 & 5 & 0.50 & 1.3 & 0.5 \\
\hline T10 & 5 & 0.40 & 1.3 & 2.5 \\
\hline T11 & 4 & 0.40 & - & $2.5(\mathrm{NaOH})$ \\
\hline T12 & 4 & 0.40 & 3.6 & 2.5 \\
\hline
\end{tabular}

Table 4

Mix design of reference samples. (WSR is water to solid ratio).

\begin{tabular}{llllllllll}
\hline Mix & R1 & R2 & R3 & R4 & R5 & R6 & R7 & R8 & R9 \\
\hline $\mathrm{Na}_{2} \mathrm{CO}_{3}$ content & $3 \%$ & $3 \%$ & $3 \%$ & $4 \%$ & $4 \%$ & $4 \%$ & $5 \%$ & $5 \%$ & $5 \%$ \\
WSR & 0.40 & 0.45 & 0.50 & 0.40 & 0.45 & 0.50 & 0.40 & 0.45 & 0.50 \\
\hline
\end{tabular}

$0.5 \%$ ) remains the same. When the sodium carbonate content is lowered to $3 \%$, compared to their references (R1-3), the TRRPs of the samples (T1-3) are shortened by about $22 \mathrm{~h}$ to $25 \mathrm{~h}$. Furthermore, the heat release change caused by the incorporated waterglass is calculated by Eq. (1) and the results are shown in Fig. 3. A clear linear correlation is observed, showing that a higher waterglass dosage corresponds to a larger changed heat.

$\Delta \mathrm{H}=\mathrm{H}_{\mathrm{M}}-\mathrm{H}_{\mathrm{R}}$

where $H_{M}(J / g)$ and $H_{R}(J / g)$ are the total heat of samples at $7 \mathrm{~d}$ activated by ternary activators and sodium carbonate (references) with the same sodium carbonate content and the same water to solid ratio, respectively.

Applying ANOVA, the percentage contributions of each factor on the TRRP and on the total heat release at 7 day are calculated separately and the results are shown in Fig. 4. Because there is only one result per trail and all columns in the orthogonal array are assigned to the influential factors, the percentage contribution of error is identical to the lowest percentage contribution of factors, i.e. percentage contribution of waterglass modulus. The percentage contribution of error of TRRP and $7 \mathrm{~d}$ heat release, $1.76 \%$ and $0.67 \%$, respectively indicates that no important factors were omitted [22]. After incorporating waterglass, the percentage contribution of factor SCC on TRRP dramatically reduces from $58.1 \%$ to $6.6 \%$, while the incorporated waterglass accounts for $19.1 \%$, indicating that the waterglass dosage plays a more significant role on TRRP than sodium carbonate content in the ternary activators system. However, the effect of waterglass modulus within the range of 1.1-1.5 is not prominent. As for the $7 \mathrm{~d}$ heat release, after incorporating waterglass to the mixtures, the dominant factor is changed from sodium carbonate content (from $95.1 \%$ to $26.4 \%$ ) to waterglass dosage $(71.8 \%$ ), while the effects of water to solid ratio and waterglass modulus are negligible. Based on the ANOVA results, the order of the factors affecting the TRRP/reaction process is derived, yielding WSR > waterglass content $>$ sodium carbonate content $>$ waterglass modulus, while for the heat release at $7 \mathrm{~d}$ the order is waterglass content $>$ sodium carbonate content $>$ WSR $>$ waterglass modulus.

\subsection{Characterization of reaction products}

The X-ray patterns of the anhydrous slag and slag activated by the ternary activators (T4-9) at the age of $28 \mathrm{~d}$ are shown in Fig. 5. The XRD patterns of the activated products show the presence of amorphous structure of $\mathrm{CaO}-\mathrm{Al}_{2} \mathrm{O}_{3}-\mathrm{MgO}-\mathrm{SiO}_{2}$ centered at $25^{\circ}-35^{\circ} 2 \theta$ and the formation of new phases, such as calcite, hydrotalcite and C-(A)-S-H gel [36]. A shift from $30^{\circ}$ to $29^{\circ} 2 \theta$ is observed after slag was activated by the ternary alkali activators, which is in line with [20, 36]. The formation of hydrotalcite is highly depending on the MgO content in the raw materials $[1,37,38]$. When the sodium carbonate content is $4 \%$, the main reaction products are calcite, $\mathrm{C}-(\mathrm{A})-\mathrm{S}-\mathrm{H}$ gel and Hydrotalcite $[36,39,40]$. When the sodium carbonate content is $5 \%$, a new phase, gaylussite $\left(\mathrm{Na}_{2} \mathrm{Ca}\left(\mathrm{CO}_{3}\right)_{2} \cdot 5 \mathrm{H}_{2} \mathrm{O}\right)$, is generated probably due to the high content of sodium carbonate, while mixes T4-6 only provide weak reflections at $13.9^{\circ}, 27.8^{\circ}$ and $32.8^{\circ} 2 \theta$.

The FTIR spectra of the ternary activators activated slag and anhydrous slag are presented in Fig. 6. Though produced with different recipes, the spectrum of all the samples exhibit similar positions, widths and intensities. After activated by the ternary activators, the wide band 

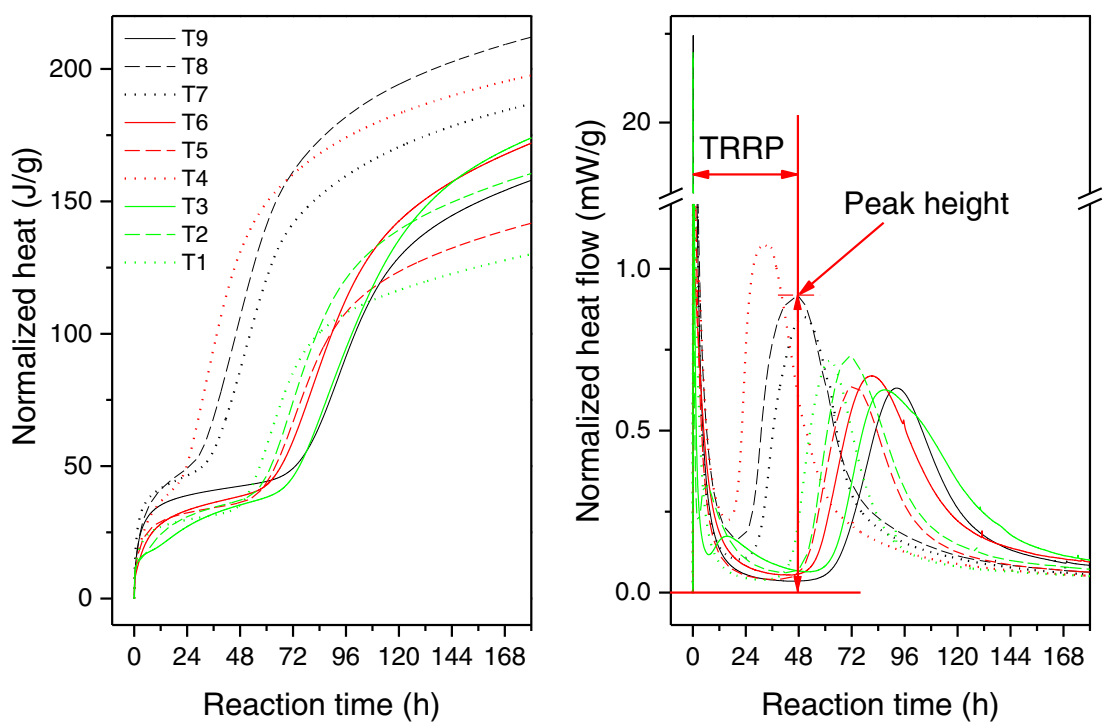

(a) (Mix T1-9)

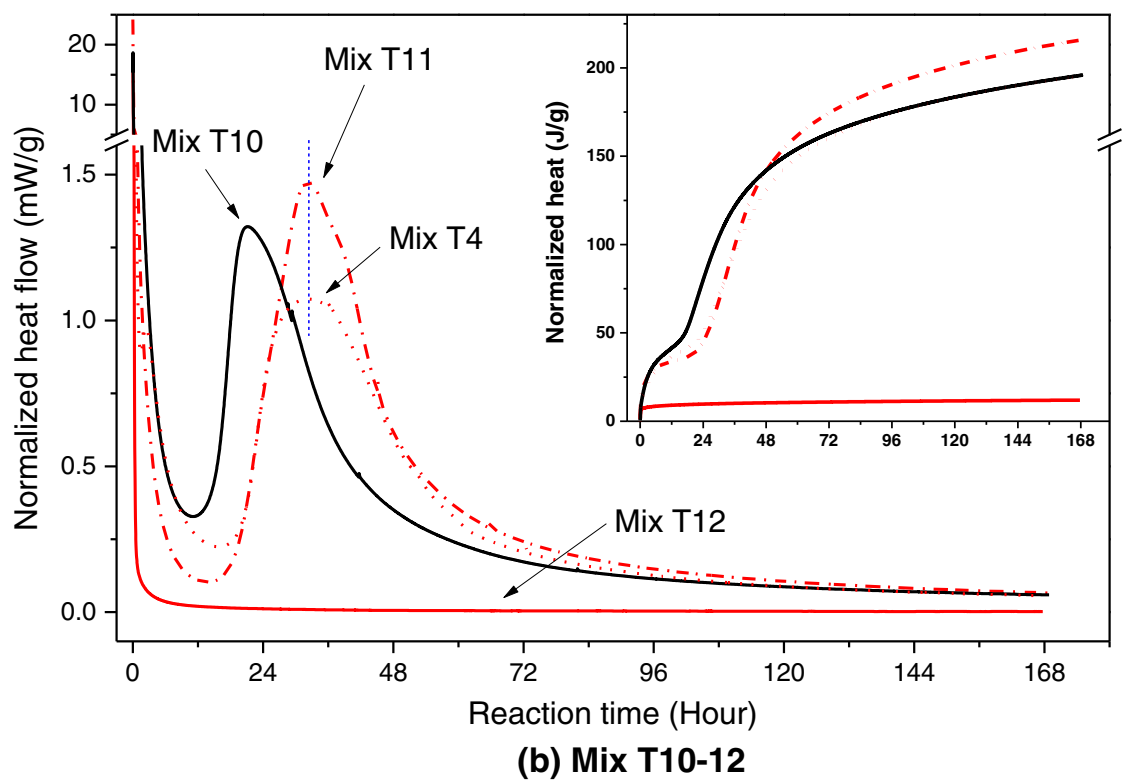

Fig. 1. Heat release of slag activated by ternary activators: (a) Mix T1-9 and (b) mix T10-12. (TRRP: time to reach the reaction peak).

centered at approximate $879 \mathrm{~cm}^{-1}$ in the IR spectrum of anhydrous slag generated by the $v_{3}[\mathrm{Si}-\mathrm{O}]$ vibration of $\mathrm{SiO}_{4}$ groups shifted to $940 \mathrm{~cm}^{-1}$ due to the formation of $\mathrm{C}-(\mathrm{A})-\mathrm{S}-\mathrm{H}$ gel $[20,37,41,42]$. The bands at $685 \mathrm{~cm}^{-1}$ caused by the vibration of $\mathrm{Al}-\mathrm{O}$ bonds in the $\mathrm{AlO}_{4}$ groups in anhydrous slag moved to a lower position of $644 \mathrm{~cm}^{-1}$ [42]. The bands at around $1412 \mathrm{~cm}^{-1}, 874 \mathrm{~cm}^{-1}$ and $711 \mathrm{~cm}^{-1}$ can be assigned to the vibration of $v_{3}\left[\mathrm{CO}_{3}^{2-}\right], v_{2}\left[\mathrm{CO}_{3}^{2-}\right]$ and $v_{4}\left[\mathrm{CO}_{3}^{2-}\right]$, respectively, which could be possibly due to the used ternary activators, the precipitated calcium carbonate or the formed hydrotalcite. In addition, the carbonation or weathering of the samples could also be partly responsible for these bonds [20]. The broad infrared spectral region appeared between $2400 \mathrm{~cm}^{-1}$ and $3720 \mathrm{~cm}^{-1}$ can be attributed to the stretching vibrations of $\mathrm{O}-\mathrm{H}$ groups [43]. Corresponding with the bond centered at $1645 \mathrm{~cm}^{-1}$, the bonds ranged between $3300 \mathrm{~cm}^{-1}$ and $3500 \mathrm{~cm}^{-1}$ are assigned to the $\mathrm{H}-\mathrm{O}-\mathrm{H}$ stretching vibrations due to the scissor bending of molecular water [43,44], while the infrared spectral region of 3650$3720 \mathrm{~cm}^{-1}$ can be attributed to the stretching modes of isolated $\mathrm{OH}$ or terminal $\mathrm{OH}$ [43].
The Si-O-Si stretch bands of $\mathrm{C}-(\mathrm{A})-\mathrm{S}-\mathrm{H}$ gel of waterglass or $\mathrm{NaOH}$ activated slag system are generally reported at the wavenumber between $950-1000 \mathrm{~cm}^{-1}$ [45-47]. However, in the spectra of the samples activated by the ternary alkali activators, the wavenumbers of the $\mathrm{Si}-\mathrm{O}-\mathrm{Si}$ peak are observed to be slightly lower, centered at $940 \mathrm{~cm}^{-1}$ (Fig. 6). According to Palacios and Puertas [48], a shift to a higher wavenumber in the infrared spectrum indicates a higher $\mathrm{Si}$ content in the $\mathrm{C}-\mathrm{S}-\mathrm{H}$ gel. It is therefore indicated that the Si content in the $\mathrm{C}-(\mathrm{A})-\mathrm{S}-\mathrm{H}$ gel is relatively low in the reaction products of slag activated by the ternary alkali activators. Puertas and Carrasco [20] studied the $\mathrm{Ca} / \mathrm{Si}$ in the reaction product of slag activated by $\mathrm{Na}_{2} \mathrm{CO}_{3} / \mathrm{NaOH}$ and waterglass, respectively. They found that $\mathrm{Na}_{2} \mathrm{CO}_{3} / \mathrm{NaOH}$ activated slag has a higher $\mathrm{Ca} / \mathrm{Si}$ ratio of 1.06 , while 0.8 in the case of waterglass. Moreover, Puertas et al. [42] analyzed the $\mathrm{Ca} / \mathrm{Si}$ ratio of slag activated by $\mathrm{NaOH}$ and waterglass and reported a low $\mathrm{Ca} / \mathrm{Si} \mathrm{C}-\mathrm{S}-\mathrm{H}$ gel $(0.7-0.8$ for waterglass and $0.9-1.0$ for $\mathrm{NaOH}$ activated slag). However, though with the additional Si element provided by the various amounts of waterglass in the designed 

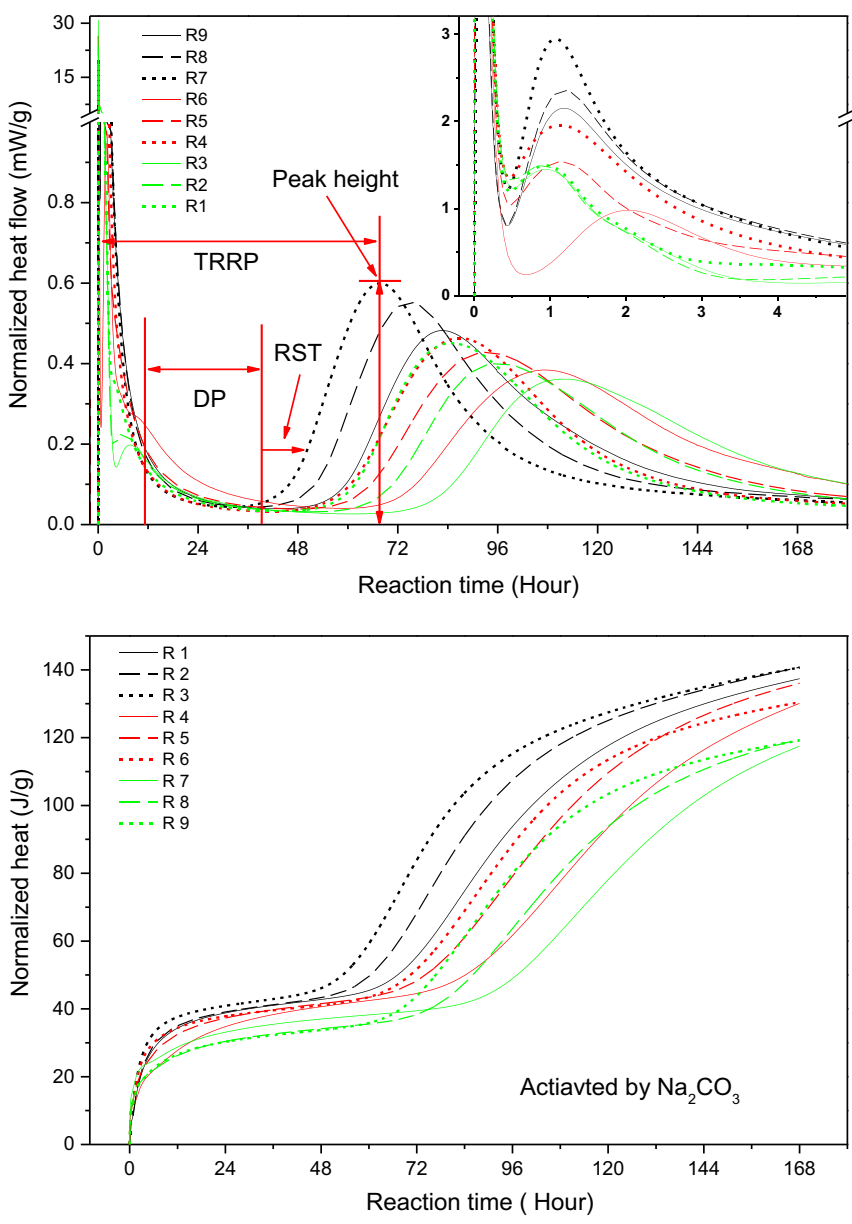

Fig. 2. Heat release of slag activated by sodium carbonate. (TRRP: time to reach the reaction peak; DP: dormant period; RST: relative setting time).

mixtures, the $\mathrm{Ca} / \mathrm{Si}$ in the samples remains similar, indicated by the same $\mathrm{Si}-\mathrm{O}-\mathrm{Si}$ peak in the FTIR spectrum. In other words, sodium carbonate plays a dominant role on the gel structure of the reaction products.

\subsection{Compressive strength}

Fig. 7 shows the compressive strength of slag activated by ternary activators at different ages ( $7 \mathrm{~d}$ and $28 \mathrm{~d}$ ) and under different curing regimes (i.e. water and $\mathrm{RH} 95 \%$ ) and their reference samples. Mix T4 provides the highest compressive strength of $63.57 \mathrm{MPa}(7 \mathrm{~d})$ and 69.10 MPa (28 d), while mix T9 gives the lowest $22.87 \mathrm{MPa}(7 \mathrm{~d}$ ) and

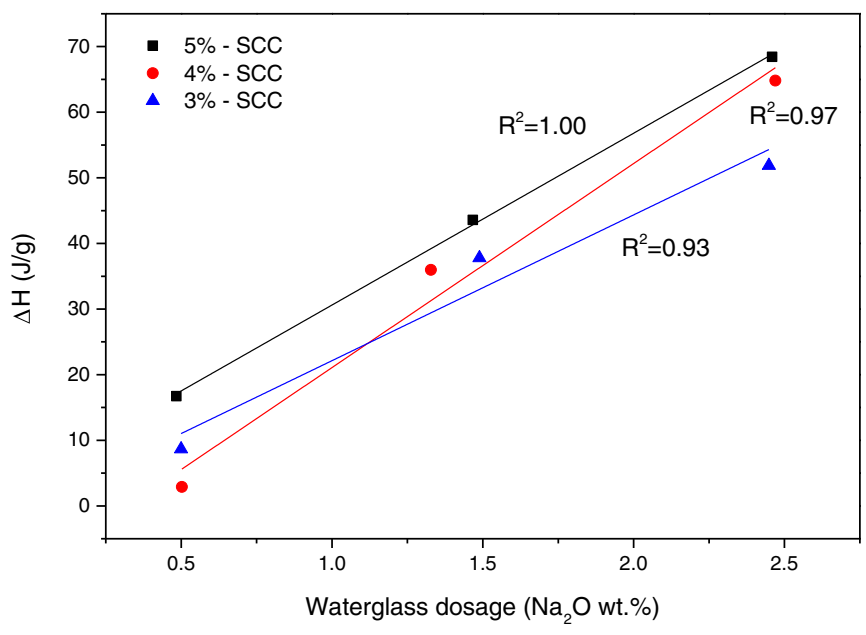

Fig. 3. $\Delta \mathrm{H}$ (changed heat release) at $7 \mathrm{~d}$ versus waterglass dosages.

36.07 MPa ( $28 \mathrm{~d}$ ). The strength gain from $7 \mathrm{~d}$ to $28 \mathrm{~d}$ of all mixtures, except T4, ranges from 10.2 MPa to 15.5 MPa, while for the references samples this is 6.9-9.9 MPa. In other words, the incorporation of waterglass not only improves the compressive strength of samples at the early age, but also provides positive effect on the strength development at later stage. In addition, the differences between the $28 \mathrm{~d}$ compressive strength of samples cured in water and $\mathrm{RH} 95 \%$ are in overall very small, indicating either of these two curing regimes is practically applicable.

The evaluation of the individual factor was performed by averaging the strength at different conditions for mixtures containing a particular factor $[22,26]$. For instance, the response index for the factor WSR at level 1 (WSR-1) is the average compressive strength of mixtures marked with WSR-1 (i.e. T1, T4 and T7). The calculated results are presented in Fig. 8. In overall, higher alkali content, lower waterglass modulus and lower water to solid ratio provide better response indexes.

The response index for the factor SCC increases with the increase of sodium carbonate content, which is in line with the previous findings [21]. A higher SCC induces a higher pH of activators and higher dissolution rate of slag particles, indicating more gels are able to be generated, resulting in a higher strength. Among all, the waterglass dosage has the most significant effect on the strength development. This phenomenon corresponds with the widely reported fact that alkali nature is the most significant factor, while in most cases waterglass is the most effective activator $[4,5,21]$. However, the effect of waterglass modulus within the range of 1.1-1.5 is not prominent, possibly due to the fact that the selected values are within the optimal range [3]. The response index for the factor WSR shows that the strength increases with the decrease of the water to solid ratio. It is obvious that adding more water will

Table 5

Reaction kinetics of slag activated by ternary activators and $\mathrm{Na}_{2} \mathrm{CO}_{3}$.

\begin{tabular}{|c|c|c|c|c|c|c|}
\hline \multirow[t]{2}{*}{ Recipes } & \multicolumn{2}{|l|}{ TRRP (h) } & \multicolumn{2}{|c|}{ Peak height (mW/g) } & \multicolumn{2}{|c|}{$7 \mathrm{~d}$ heat release $(\mathrm{J} / \mathrm{g})$} \\
\hline & Ternary & References & Ternary & References & Ternary & References \\
\hline 1 & $62 \mathrm{~h}: 05 \mathrm{~min}$ & $84 \mathrm{~h}: 40 \mathrm{~min}$ & 0.72 & 0.45 & 127.77 & 119.11 \\
\hline 2 & $70 \mathrm{~h}: 53 \mathrm{~min}$ & $95 \mathrm{~h}: 50 \mathrm{~min}$ & 0.73 & 0.40 & 157.29 & 119.49 \\
\hline 3 & $87 \mathrm{~h}: 02 \mathrm{~min}$ & $111 \mathrm{~h}: 36 \mathrm{~min}$ & 0.63 & 0.36 & 169.37 & 117.50 \\
\hline 4 & $32 \mathrm{~h}: 15 \mathrm{~min}$ & $86 \mathrm{~h}: 52 \mathrm{~min}$ & 1.07 & 0.46 & 195.26 & 130.45 \\
\hline 5 & $72 \mathrm{~h}: 33 \mathrm{~min}$ & $92 \mathrm{~h}: 57 \mathrm{~min}$ & 0.64 & 0.43 & 138.94 & 136.05 \\
\hline 6 & $83 \mathrm{~h}: 04 \mathrm{~min}$ & $107 \mathrm{~h}: 08 \mathrm{~min}$ & 0.67 & 0.38 & 166.87 & 130.15 \\
\hline 7 & $50 \mathrm{~h}: 11 \mathrm{~min}$ & $67 \mathrm{~h}: 46 \mathrm{~min}$ & 0.85 & 0.60 & 184.29 & 140.70 \\
\hline 8 & $47 \mathrm{~h}: 34 \mathrm{~min}$ & $75 \mathrm{~h}: 15 \mathrm{~min}$ & 0.92 & 0.55 & 209.22 & 140.78 \\
\hline 9 & $92 \mathrm{~h}: 19 \mathrm{~min}$ & $82 \mathrm{~h}: 56 \mathrm{~min}$ & 0.63 & 0.48 & 154.10 & 137.37 \\
\hline 10 & $21 \mathrm{~h}: 07 \mathrm{~min}$ & $67 \mathrm{~h}: 46 \mathrm{~min}$ & 1.32 & 0.60 & 195.79 & 140.70 \\
\hline 11 & $32 \mathrm{~h}: 09 \mathrm{~min}$ & $86 \mathrm{~h}: 52 \mathrm{~min}$ & 1.48 & 0.46 & 215.82 & 130.45 \\
\hline 12 & - & $86 \mathrm{~h}: 52 \mathrm{~min}$ & - & 0.46 & 11.95 & 130.45 \\
\hline
\end{tabular}




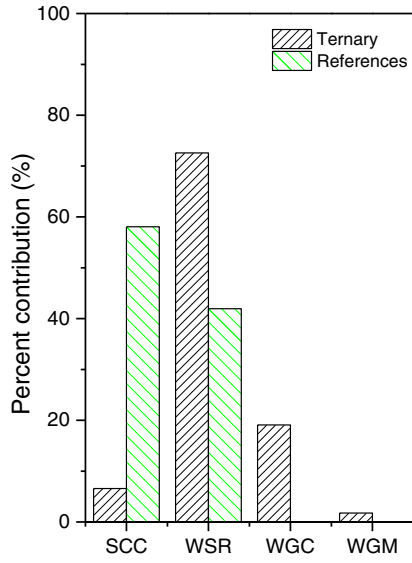

(a)

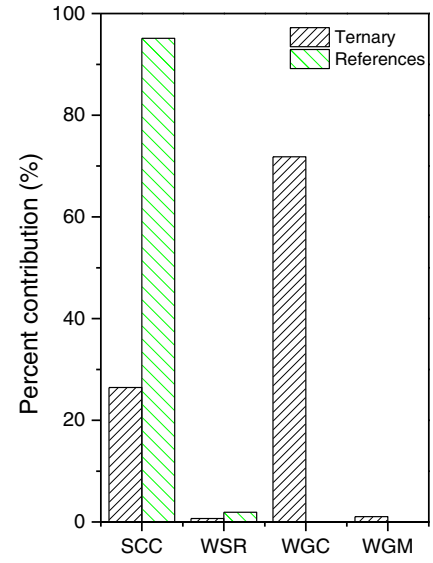

(b)
Fig. 4. Percentage contribution by different factors on: (a) TRRP; (b) $7 \mathrm{~d}$ heat release.

result in a higher porosity of products, leading to a lower strength. Moreover, more water will cause a dilution effect of the used alkali activators, leading to a retardation of the reaction process.

Furthermore, the percentage contribution of each factor on the compressive strength at different ages and different curing regimes is evaluated by applying ANOVA (see Fig. 9a). The percentage contributions of error of strength development at the curing ages of $7 \mathrm{~d}$ and $28 \mathrm{~d}, 2.22 \%$ and $5.58 \%$, indicate that no important factors were omitted in this investigation [22]. It is obvious that the waterglass content plays a dominant role on the compressive strength, followed by water to solid ratio and sodium carbonate, while the contribution of waterglass modulus is relatively low. In overall, though with lower contents, the contribution of waterglass is more significant than sodium carbonate on the strength development. Moreover, the effect of waterglass dosage is evaluated by calculating the strength differences between mixtures activated by ternary activators and by mixtures activated by sodium carbonate, and the results are shown in Fig. 9b. It is clear that the waterglass dosage contributes linearly to the strength development.

\subsection{Discussion}

As confirmed by the calorimetry experiment results (Fig. 2), the reaction rate of slag activated by only sodium carbonate is significantly low, indicated by a long dormant period which is caused by the initial precipitation of calcium carbonate. Owing to the addition of waterglass

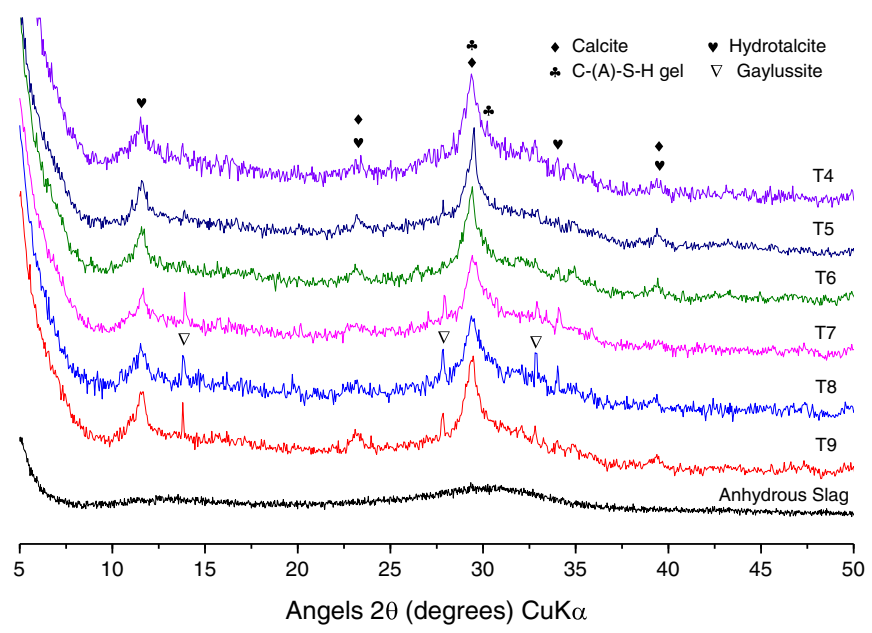

Fig. 5. XRD patterns of anhydrous slag and slag activated by ternary activators (mix T4-9).

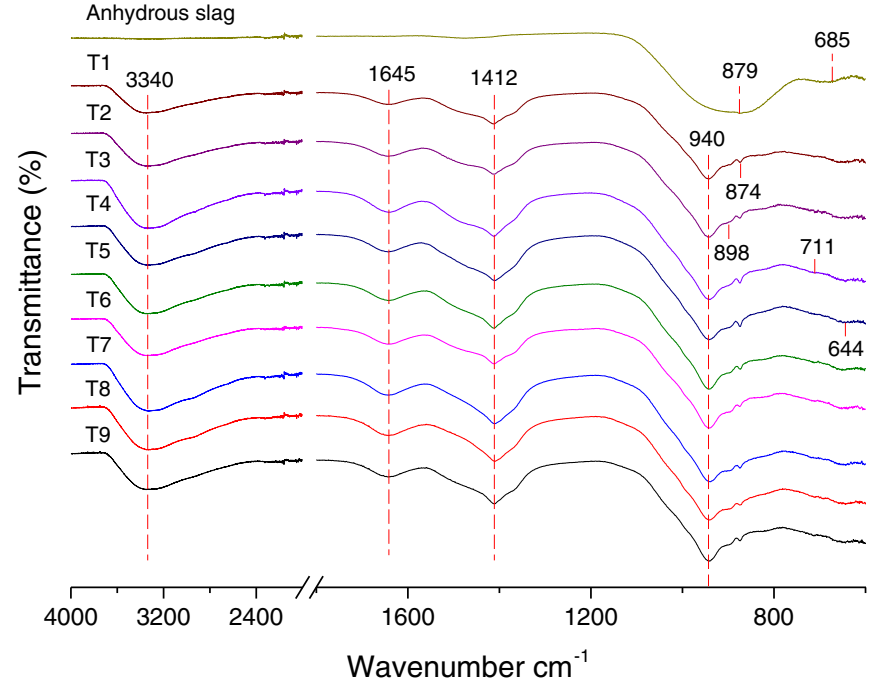

Fig. 6. FTIR spectra of anhydrous slag and slag activated by ternary activators.

$\left(\mathrm{Na}_{2} \mathrm{O} \cdot \mathrm{rSiO}_{2} \cdot \mathrm{nH}_{2} \mathrm{O}\right)$, the reaction process is promoted by two possible mechanisms. The first one is related to the $\mathrm{pH}$ of alkaline solution increased by the additional $\mathrm{Na}_{2} \mathrm{O}$ content in waterglass, which has the similar effect as $\mathrm{NaOH}$ [18-20]. The second one is the additional $\mathrm{Si}$ element provided by waterglass $\left(\mathrm{rSiO}_{2}\right)$, which will trigger the formation of $\mathrm{C}-(\mathrm{A})-\mathrm{S}-\mathrm{H}$ gel, consuming carbonate anions and promoting the strength development especially at the early stage. The first mechanism is clearly observed as indicated by the dominant role of waterglass dosages (based on $\mathrm{Na}_{2} \mathrm{O}$ wt.\% content) on reaction rate and strength development, while the second mechanism is not prominent since the effect of WGM on reaction is negligible.

To further analyze the role of WGM, three additional mixtures were designed (Table $3 \mathrm{~b}$ ) and tested on the heat release (Fig. 1b) and compressive strength (Fig. 7b), including T10 (highest alkali content and lowest WSR), T11 $\left(\mathrm{NaOH}+\mathrm{Na}_{2} \mathrm{CO}_{3}\right)$ and $\mathrm{T} 12$ (waterglass $+\mathrm{Na}_{2} \mathrm{CO}_{3}$ ). The calorimetry experiment results show that when the modulus of waterglass reaches a certain level (T12, modulus 3.61), the reaction process is significantly retarded and the sample remains soft approximately $7 \mathrm{~d}$ after casting. While slag activated by the mixture of $\mathrm{NaOH}$ and $\mathrm{Na}_{2} \mathrm{CO}_{3}$ (T11) shows a fast reaction rate but with relative low compressive strength (only slight higher than its reference sample R4). The time to reach the reaction peak of T11 and T4 is very similar but the peak height of T11 is higher. Comparing the calorimetry results of T4, T11 and T12, it is clear that under a certain level the influence of WGM on the reaction process is negligible, while beyond this the reaction process will be dramatically delayed. On the other hand, though the influence of WGM on the compressive strength is not prominent within the range of 1.1-1.5, the low compressive strength of $\mathrm{T} 11$ shows that additional $\mathrm{Si}$ element supplied by waterglass provides a significant effect on the strength development.

Cengiz et al. [12] studied the influence of waterglass modulus on the compressive strength using slag and $\mathrm{NaOH}$ modified waterglass as raw materials and reported that at high alkali concentrations lower WGMs give better strength. Wang [4] studied the factors affecting the compressive strength of waterglass activated slag and concluded that the optimum moduli of waterglass is highly depending on the used slag, i.e. $1.0-1.5$ for basic slag, $0.9-1.3$ for neutral slag and $0.75-1.25$ for acid slag. A recent study shows that when the modulus of waterglass is higher than 2.5, the heat release of reaction peak is delayed and barely noticeable [49]. In this paper, the studied moduli of waterglass, 1.1-1.5, is within the optimum range, which can possibly be the reason that the very little effect the WGM shows.

It is obvious that waterglass dosage is a determinant on the compressive strength. The reason could be related to the nature of 


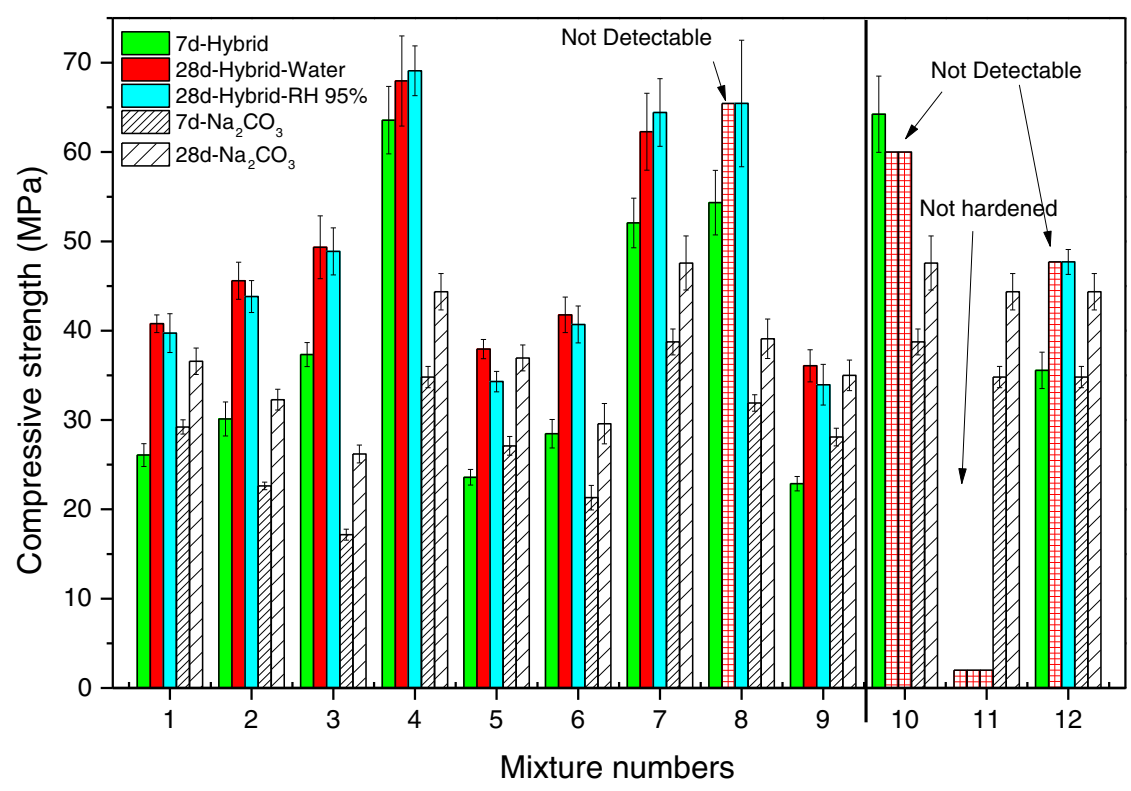

Fig. 7. Compressive strength of slag activated by ternary activators and $\mathrm{Na}_{2} \mathrm{CO}_{3}$ only.

alkaline activators on the structure of calcium silicate hydrates formed. Using ${ }^{29} \mathrm{Si}$ MAR-NMR spectra analysis, Jimenez [37] found that slag activated by waterglass favors the formation of cross-linked structures due to the contents of $Q^{2}$ and $Q^{3}$ silicon, resulting in a high strength. While slag activated by $\mathrm{Na}_{2} \mathrm{CO}_{3}$ shows lower strength because of its lower $Q^{2}$ silicon. However, the reaction products are not influenced by the waterglass content in the ternary activators system. Characterized by $\mathrm{XRD}$, the main reaction products are $\mathrm{C}-(\mathrm{A})-\mathrm{S}-\mathrm{H}$ gel, calcite, hydrotalcite and possibly gaylussite depending on the sodium carbonate content in the mixtures. Puertas and Carrasco [20] reported that the XRD pattern of slag activated by waterglass or hybrid activators $\left(\mathrm{Na}_{2} \mathrm{CO}_{3}\right.$ and $\left.\mathrm{NaOH}\right)$ are similar and the main reaction products are calcite, $\mathrm{C}-\mathrm{A}-\mathrm{S}-\mathrm{H}$ gel and hydrotalcite. On the other hand, the $\mathrm{Ca} / \mathrm{Si}$ ratio in the $\mathrm{C}-(\mathrm{A})-\mathrm{S}-\mathrm{H}$ gel indicated by the FTIR spectra is relatively low. Nevertheless, the FTIR spectra of all samples are similar and are not affected by the varied mix proportions of alkali activators, indicating the gel structure is primarily controlled by sodium carbonate.

The results confirmed that higher waterglass dosages, higher sodium carbonate contents and lower water to solid ratios will lead to a higher strength and faster reaction rate. However, when the sodium

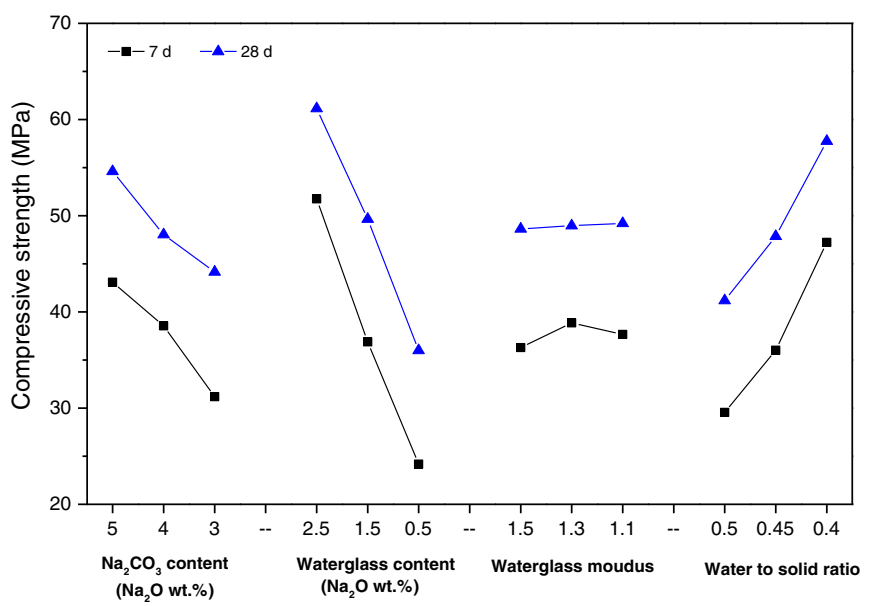

Fig. 8. Response index versus investigated factors. carbonate content is higher than $5 \%$, increasing the waterglass dosage over $1.5 \%$ will cause significant cracks on the surface of samples. The compressive strength of some samples were not able to be tested, measured as shown in Fig. 7. The reasons for this phenomenon are generally correlated to the visible cracks appeared on the surface of specimens. In addition, the incorporation of waterglass in the ternary activators system will also decrease the solubility of sodium carbonate. The studied alkali concentration of sodium carbonate and $\mathrm{NaOH}$ modified waterglass is presented in Fig. 10. Though the concentration of sodium carbonate in mix T10 is below the saturation limit, about 1$2 \mathrm{~g}$ of $\mathrm{Na}_{2} \mathrm{CO}_{3}$ is not dissolved in the water (measured by a balance). Clearly when the alkali dosage is too high, negative effects of hybrid activators are observed. In this case, a controlled amount of sodium carbonate up to $4 \%$ is suggested as waterglass has more influence on the reaction rate and strength development. Based on the reaction kinetics analysis and the compressive strength results, an optimal mix recipe, waterglass content of $2.5 \%$, waterglass modulus of $1.1-1.5$, sodium carbonate content of $4 \%$ and water to solid ratio of 0.4 , is proposed for the ternary activators.

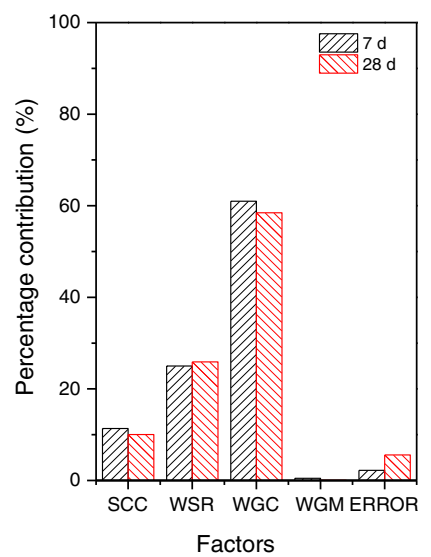

(a)

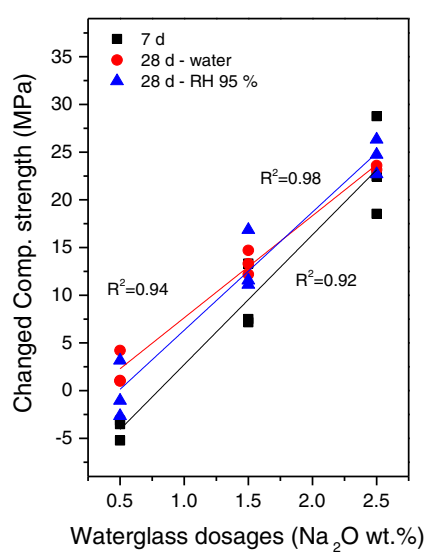

(b)
Fig. 9. (a) Percentage contribution of factors on strength development; (b) effect of waterglass dosages on compressive strength. 


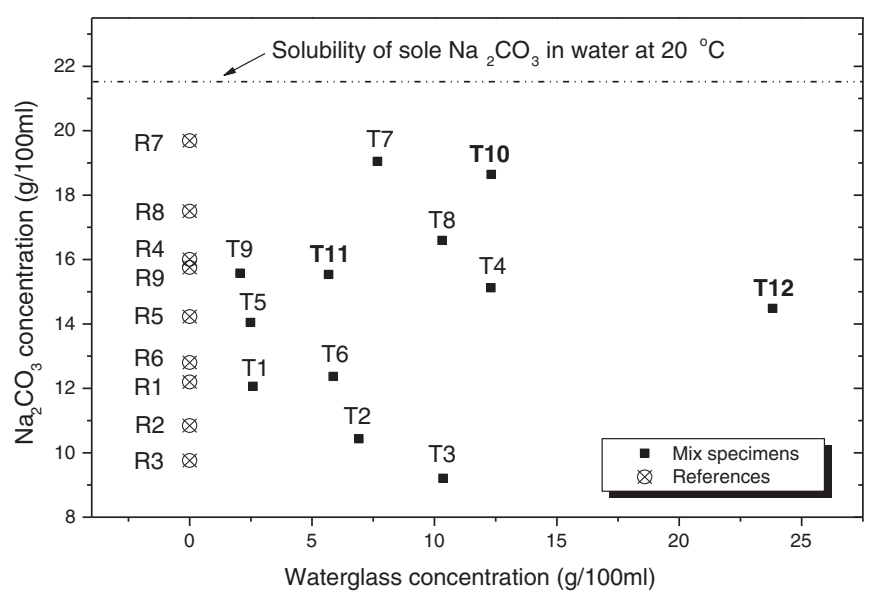

Fig. 10. The relationship of the used sodium carbonate and waterglass dosage in the designed recipes.

\section{Conclusions}

Applying the Taguchi method, the effect of influential factors on the reaction kinetics and compressive strength of ternary activators activated slag was evaluated. The resulted products were further characterized by XRD and FTIR analyses. The following conclusions are drawn:

1. The reaction of slag activated by ternary activators is significantly accelerated compared to sole sodium carbonate activated slag, with the time to reach reaction peak shortened up to about $54 \mathrm{~h}$.

2. Sodium carbonate dominates the reaction products and gel structure of ternary activators activated slag.

3. Waterglass dosage is the determinant of the compressive strength of ternary activators activated slag.

4. An optimal proportion of ternary alkali activators (SCC 4\%, WGC $2.5 \%$, WGM 1.1-1.5 and WSR 0.4) is proposed.

\section{Acknowledgments}

This research was carried out under the fund of China Scholarship Council (No.201306950030). Furthermore, the authors wish to express their gratitude to the following sponsors of the Building Materials research group at TU Eindhoven: Rijkswaterstaat Grote Projecten en Onderhoud, Graniet-Import Benelux, Kijlstra Betonmortel, Struyk Verwo, Attero, Enci, Rijkswaterstaat Zee en Delta - District Noord, Van Gansewinkel Minerals, BTE, V.d. Bosch Beton, Selor, GMB, Geochem Research, Icopal, BN International, Eltomation, Knauf Gips, Hess AAC Systems, Kronos, Joma, CRH Europe Sustainable Concrete Centre, Cement\&BetonCentrum, Heros and Inashco.

\section{References}

[1] M.B. Haha, G.L. Saout, F. Winnefeld, B. Lothenbach, Influence of activator type on hydration kinetics, hydrate assemblage and microstructural development of alkali activated blast-furnace slags, Cem. Concr. Res. 41 (2011) 301-310, http://dx.doi.org/10.1016/j.cemconres.2010.11.016.

[2] A.F. Jimenez, F. Puertas, Setting of alkali-activated slag cement. Influence of activator nature, Adv. Cem. Res. 13 (2001) 115-121.

[3] A.M. Rashad, A comprehensive overview about the influence of different additives on the properties of alkali-activated slag - a guide for Civil Engineer, Constr. Build. Mater. 47 (2013) 29-55, http://dx.doi.org/10.1016/j.conbuildmat.2013.04. 011.

[4] S. Wang, K.L. Scrivener, P.L. Pratt, Factors affecting the strength of alkali-activated slag, Cem. Concr. Res. 24 (1994) 1033-1043.

[5] T. Bakharev, J.G. Sanjayan, Y.B. Cheng, Alkali activation of Australian slag cements, Cem. Concr. Res. 29 (1999) 113-120, http://dx.doi.org/10.1016/S0008-8846(98)00170-7.

[6] European Commission, Reference Document on Best Available Techniques for the Manufacture of Large Volume Inorganic Chemicals - Solids and Other Industry, 2007.
[7] N.K. Lee, H.K. Lee, Setting and mechanical properties of alkali-activated fly ash/slag concrete manufactured at room temperature, Constr. Build. Mater. 47 (2013) 1201-1209, http://dx.doi.org/10.1016/j.conbuildmat.2013.05.107.

[8] M. Palacios, F. Puertas, Effect of shrinkage-reducing admixtures on the properties of alkali-activated slag mortars and pastes, 37 (2007) 691-702, http://dx.doi.org/10. 1016/j.cemconres.2006.11.021.

[9] A.A. Melo, M. Alba, W. Repette, Drying and autogenous shrinkage of pastes and mortars with activated slag cement, 38 (2008) 565-574, http://dx.doi.org/10. 1016/j.cemconres.2007.11.002.

[10] C. Gong, N. Yang, Effect of phosphate on the hydration of alkali-activated red mudslag cementitious material, Cem. Concr. Res. 30 (2000) 1013-1016, http://dx.doi.org/ 10.1016/S0008-8846(00)00260-X

[11] J.J. Chang, A study on the setting characteristics of sodium silicate-activated slag pastes, Cem. Concr. Res. 33 (2003) 1005-1011, http://dx.doi.org/10.1016/S00088846(02)01096-7.

[12] C. Duran Atis, C. Bilim, O. Celik, O. Karahan, Influence of activator on the strength and drying shrinkage of alkali-activated slag mortar, Constr. Build. Mater. 23 (2009) 548-555, http://dx.doi.org/10.1016/j.conbuildmat.2007.10.011.

[13] C. Bilim, O. Karahan, C.D. Atiş, S. Ilkentapar, Influence of admixtures on the properties of alkali-activated slag mortars subjected to different curing conditions, Mater. Des. 44 (2013) 540-547, http://dx.doi.org/10.1016/j.matdes.2012.08.049.

[14] M. Palacios, Y.F. Houst, P. Bowen, F. Puertas, Adsorption of superplasticizer admixtures on alkali-activated slag pastes, Cem. Concr. Res. 39 (2009) 670-677, http://dx.doi.org/10.1016/j.cemconres.2009.05.005.

[15] M. Palacios, F. Puertas, Effect of superplasticizer and shrinkage-reducing admixtures on alkali-activated slag pastes and mortars, Cem. Concr. Res. 35 (2005) 1358-1367, http://dx.doi.org/10.1016/j.cemconres.2004.10.014.

[16] A.M. Rashad, Y. Bai, P.A.M. Basheer, N.B. Milestone, N.C. Collier, Hydration and properties of sodium sulfate activated slag, Cem. Concr. Compos. 37 (2013) 20-29, http://dx.doi.org/10.1016/j.cemconcomp.2012.12.010.

[17] V. Zivica, Effects of type and dosage of alkaline activator and temperature on the properties of alkali-activated slag mixtures, Constr. Build. Mater. 21 (2007) 1463-1469, http://dx.doi.org/10.1016/j.conbuildmat.2006.07.002.

[18] F. Collins, J.G. Sanjayan, Early age strength and workability of slag pastes activated by $\mathrm{NaOH}$ and $\mathrm{Na}_{2} \mathrm{CO}_{3}$, Cem. Concr. Res. 28 (1998) 655-664.

[19] T. Bakharev, J.G. Sanjayan, Y.B. Cheng, Effect of admixtures on properties of alkaliactivated slag concrete, Cem. Concr. Res. 30 (2000) 1367-1374, http://dx.doi.org/ 10.1016/S0008-8846(00)00349-5

[20] F. Puertas, M.T. Carrasco, Use of glass waste as an activator in the preparation of alkali-activated slag. Mechanical strength and paste characterisation, Cem. Concr. Res. 57 (2014) 95-104, http://dx.doi.org/10.1016/j.cemconres.2013.12.005.

[21] A.F. Jimenez, J.G. Palomo, F. Puertas, Alkali-activated slag mortars: mechanical strength behaviour, Cem. Concr. Res. 29 (1999) 1313-1321.

[22] P.J. Ross, Taguchi Techniques for Quality Engineering, McGraw-Hill, New York, 1988.

[23] A. Bagheri, A. Nazari, Compressive strength of high strength class C fly ash-based geopolymers with reactive granulated blast furnace slag aggregates designed by Taguchi method, Mater. Des. 54 (2014) 483-490, http://dx.doi.org/10.1016/j.matdes. 2013.07.035.

[24] A. Nazari, H. Khanmohammadi, M. Amini, H. Hajiallahyari, A. Rahimi, Production geopolymers by Portland cement: designing the main parameters' effects on compressive strength by Taguchi method, Mater. Des. 41 (2012) 43-49, http://dx.doi.org/10.1016/j.matdes.2012.04.045.

[25] S. Riahi, A. Nazari, The effects of nanoparticles on early age compressive strength of ash-based geopolymers, Ceram. Int. 38 (2012) 4467-4476, http://dx.doi.org/10. 1016/j.ceramint.2012.02.021.

[26] M.J.A. Mijarsh, M.A. Megat Johari, Z.A. Ahmad, Synthesis of geopolymer from large amounts of treated palm oil fuel ash: application of the Taguchi method in investigating the main parameters affecting compressive strength, Constr. Build. Mater. 52 (2014) 473-481, http://dx.doi.org/10.1016/j.conbuildmat.2013.11.039.

[27] M. Olivia, H. Nikraz, Properties of fly ash geopolymer concrete designed by Taguchi method, Mater. Des. 36 (2012) 191-198, http://dx.doi.org/10.1016/j.matdes.2011.10. 036.

[28] British Standard En 196-1, Methods of Testing Cement Part 1: Determination of Strength, 2005.

[29] S. Puligilla, P. Mondal, Role of slag in microstructural development and hardening of fly ash-slag geopolymer, Cem. Concr. Res. 43 (2013) 70-80, http://dx.doi.org/10. 1016/j.cemconres.2012.10.004.

[30] S.A. Bernal, J.L. Provis, V. Rose, R. Mejia De Gutierrez, Evolution of binder structure in sodium silicate-activated slag-metakaolin blends, Cem. Concr. Compos. 33 (2011) 46-54, http://dx.doi.org/10.1016/j.cemconcomp.2010.09.004.

[31] A.R. Brough, A. Atkinson, Sodium silicate-based, alkali-activated slag mortars Part I. Strength, hydration and microstructure, Cem. Concr. Res. 32 (2002) 865-879.

[32] Z. Tan, G. De Schutter, G. Ye, Y. Gao, L. Machiels, Influence of particle size on the early hydration of slag particle activated by $\mathrm{Ca}(\mathrm{OH}) 2$ solution, Constr. Build. Mater. 52 (2014) 488-493, http://dx.doi.org/10.1016/j.conbuildmat.2013.11.073.

[33] A.F. Jimenez, F. Puertas, Alkali activated slag cement: kinetic studies, Cem. Concr. Res. 27 (1997) 359-368.

[34] F. Han, R. Liu, D. Wang, P. Yan, Characteristics of the hydration heat evolution of composite binder at different hydrating temperature, Thermochim. Acta (2014) http://dx.doi.org/10.1016/j.tca.2014.04.010.

[35] L. Wadso, Applications of an eight-channel isothermal conduction calorimeter for cement hydration studies, Cem. Int. 5 (2005) 94-101.

[36] F. Jin, K. Gu, A.A. Tabbaa, Strength and drying shrinkage of reactive MgO modified alkali-activated slag paste, Constr. Build. Mater. 51 (2014) 395-404, http://dx.doi. org/10.1016/j.conbuildmat.2013.10.081. 
[37] A.F. Jimenez, F. Puertas, Structure of calcium silicate hydrates formed in alkalineactivated slag: influence of the type of alkaline activator, J. Am. Ceram. Soc. 94 (2003) 1389-1394.

[38] S.A. Bernal, R.S. Nicolas, R.J. Myers, R. Mejia De Gutierrez, F. Puertas, J.S.J. Van Deventer, et al., MgO content of slag controls phase evolution and structural changes induced by accelerated carbonation in alkali-activated binders, Cem. Concr. Res. 57 (2014) 33-43, http://dx.doi.org/10.1016/j.cemconres.2013.12.003.

[39] I.G. Richardson, A.R. Brough, G.W. Groves, C.M. Dobson, The characterization of hardened alkali-activated blast-furnace slag pastes and the nature of the calcium silicate hydrate (C-S-H) phase, Cem. Concr. Res. 24 (1994) 813-829.

[40] S. Wang, K.L. Scrivener, Hydration products of alkali activated slag cement, Cem. Concr. Res. 25 (1995) 561-571, http://dx.doi.org/10.1016/0008-8846(95)00045-E.

[41] F. Puertas, M. Palacios, H. Manzano, J.S. Dolado, A. Rico, J. Rodriguez, A model for the C-A-S-H gel formed in alkali-activated slag cements, J. Eur. Ceram. Soc. 31 (2011) 2043-2056, http://dx.doi.org/10.1016/j.jeurceramsoc.2011.04.036.

[42] F. Puertas, A.F. Jimenez, M.T. Blanco-Varela, Pore solution in alkali-activated slag cement pastes. Relation to the composition and structure of calcium silicate hydrate, Cem. Concr. Res. 34 (2004) 139-148, http://dx.doi.org/10.1016/S0008-8846(03)00254-0.

[43] P. Innocenzi, Infrared spectroscopy of sol-gel derived silica-based films: a spectra-microstructure overview, J. Non-Cryst. Solids 316 (2003) 309-319, http://dx.doi.org/10.1016/S0022-3093(02)01637-X.
[44] M.O. Yusuf, M.A. Megat Johari, Z.A. Ahmad, M. Maslehuddin, Strength and microstructure of alkali-activated binary blended binder containing palm oil fue ash and ground blast-furnace slag, Constr. Build. Mater. 52 (2014) 504-510, http://dx.doi.org/10.1016/j.conbuildmat.2013.11.012.

[45] D. Ravikumar, N. Neithalath, Effects of activator characteristics on the reaction product formation in slag binders activated using alkali silicate powder and $\mathrm{NaOH}$, Cem. Concr. Compos. 34 (2012) 809-818, http://dx.doi.org/10.1016/j. cemconcomp.2012.03.006.

[46] I. Garcia Lodeiro, D.E. Macphee, A. Palomo, A.J. Fernandez, Effect of alkalis on fresh C-S-H gels. FTIR analysis, Cem. Concr. Res. 39 (2009) 147-153, http://dx.doi.org/ 10.1016/j.cemconres.2009.01.003.

[47] I. Garcia-Lodeiro, A.F. Jimenez, M.T. Blanco, A. Palomo, FTIR study of the sol-gel synthesis of cementitious gels: C-S-H and N-A-S-H, J. Sol-Gel Sci. Technol. 45 (2007) 63-72, http://dx.doi.org/10.1007/s10971-007-1643-6.

[48] M. Palacios, F. Puertas, Effect of carbonation on alkali-activated slag paste, J. Am. Ceram. Soc. 89 (2006) 3211-3221, http://dx.doi.org/10.1111/j.1551-2916.2006. 01214.x.

[49] D. Ravikumar, N. Neithalath, Reaction kinetics in sodium silicate powder and liquid activated slag binders evaluated using isothermal calorimetry, Thermochim. Acta 546 (2012) 32-43, http://dx.doi.org/10.1016/j.tca.2012.07.010. 